\title{
Exploration on the problems and deepening ways of International Exchange and Cooperation in Colleges and Universities
}

\author{
WenJun Lu \\ Beifang University of Nationallities Yinchuan City, Ningxia,China
}

\begin{abstract}
Keywords: International exchange of colleges and universities; talent introduction; exploration approach.
\end{abstract}

\begin{abstract}
With the continuous development of economic globalization, international exchange and cooperation between colleges and universities has become an important trend in the development of higher education teaching.Under the background of economic globalization, the international exchange and cooperation between colleges and universities has provided a new opportunity for higher education in our country.It can not only let other countries see the development achievements of educational and teaching activities in colleges and universities in our country, but also absorb the advanced experience of running schools and the concept of education and teaching in foreign countries, thus promoting the further development of colleges and universities in our country. This paper mainly probes into the problems existing in the process of international exchange and cooperation in colleges and universities and the ways to deepen them. It hopes to provide some reference for the sustainable and stable development of the university in our country.
\end{abstract}

\section{Preface}

The continuous acceleration of economic globalization has led to a gradual increase in the degree of integration of China's economic development with the world. The education and Teaching training of High level and High quality talents play a vital role in the sustainable development of our economy. The international exchange and cooperation of colleges and universities has become an important embodiment of the current economic globalization, and it is also the inevitable trend of the development of education and teaching in the future. We can effectively solve the problems faced in the current educational and teaching activities in our country, improve the overall quality of education and teaching in our country, give full play to the advantages of educational and teaching activities, and promote the cultivation of high-level talents through the integration and communication between colleges and universities in various countries.

\section{The importance of International Exchange and Cooperation of Colleges and Universities}

The international exchange and cooperation between colleges and universities is the exchange between advanced science and technology and high quality and high level talents, and it is also an exchange activity that cuts across cultures, nationalities and national boundaries. There are many forms of international communication between colleges and universities, such as the exchange of scholars, the exchange of teachers and students, the study of international cooperation, the running of schools by international cooperation, the international conference and the assistance of international resources, etc. As the main source of science and technology innovation and the key area of human resource development, colleges and universities are closely related to the development of social economy and the transformation of advanced productivity. From the current point of view, there is still a certain gap between the quality of education and the level of personnel training in colleges and universities in China and those in developed countries. There are some shortcomings in the degree of internationalization, the funds for running schools, the level of management and the level of teachers, which affect the further improvement of the quality of education and teaching in our country. In order to further improve the school-running level of our country, and shorten the gap between the university and the first-class colleges and universities in our country, we have to strengthen international exchanges and cooperation among colleges and universities, and actively absorb advanced and 
efficient experience and ideas in running schools, and try to establish an international high-level teacher team based on the specific development situation and development requirements of colleges and universities, so as to create a good environment and providing the faculty for the smooth implementation of the teaching activities. Universities all over the world are rooted in their own historical environment and cultural characteristics, and they all have their own style and tradition of running schools. In the process of international exchanges and cooperation in colleges and universities, we should fully respect the cultural habits and customs and beliefs of different countries, and expand our international horizons. We should also make breakthrough and innovation of the concept of education and teaching in colleges and universities in our country with the help of the advanced advantages of other countries in running schools. At the same time, we can also make foreign colleges and universities realize the achievements of the development of higher education and teaching in our country, and enhance the international popularity and influence of colleges and universities in our country by deepening international exchanges and cooperation, thus attracting more excellent international students to study in China, and providing a large number of high-level and high-quality international talents for the development of our social and economic development. ${ }^{[1]}$

\section{Problems existing in the process of International Exchange and Cooperation in Colleges and Universities currently}

\subsection{The language barriers}

Because the language system of our country has its own origins, we will encounter some language barriers when communicating with the top international colleges and universities. The language gap between us and the developed colleges and universities and in the world may limit the smooth implementation of the concept of international and exchange cooperative teaching and the orderly development of educational and teaching activities in China to a great extent. As a common language in the world, English plays a very important role in the process of cooperative communication in colleges and universities. However, at present, the vast majority of colleges and universities in our country are implementing their teaching activities by mainly using Chinese, which is seriously derailed with the international. As a result, the international communication ability and cooperation ability of colleges and universities are relatively poor, which affects the expansion and renewal of the concept of education and teaching in our country. What's more, it is difficult for us to get our rightful place in various international exchange conferences and projects. In the meantime, many colleges and universities of our country can not carry out the teaching activities with pure English, which restricts the study of foreign students in China. It also affects the smooth development of international projects due to the poor English level of teachers in many colleges and universities of our country. As a result, the proportion of foreign teachers and the proportion of foreign students in China are relatively low compared with those in developed countries. This factors also affects the sustained and stable development of China's international cooperation and exchanges. ${ }^{[2]}$

\subsection{Lacking of understanding of the cooperative object}

Strengthening international exchange and cooperation has become an important form and content of education and teaching. All levels and all kinds of colleges and universities should actively carry out various forms of international exchanges and cooperation, implement the project of international cooperation in running schools well, and establish Sino-foreign cooperative schools well, in addition, they should also improve the level of education and teaching in our country, and promote the construction of economic modernization and the reform and development of education in our country by making full use of foreign high-quality education and teaching resources. However, judging from the actual situation of international exchanges and cooperation in colleges and universities, many colleges and universities lack a correct understanding of the object of cooperation, and lack of intuitive and accurate understanding of the scientific research level and educational quality of colleges and universities in the cooperative area, thus affecting the depth of international exchanges and cooperation. They can't make full use of and develop the high-quality educational and teaching 
resources of cooperative universities, which also affects the level of cooperation and exchange. With the continuous acceleration of the process of economic integration, the international exchanges and cooperation objects of colleges and universities show a diversified development trend. It should only limited to the exchanges and cooperation between different schools. Colleges and universities can also carry out education and teaching cooperation with international organizations, foreign governments, scientific research institutions and famous enterprises, so as to make the form of cooperation more diversified and extensive. The international exchanges and cooperation between colleges and universities are also reflected in the establishment of cooperation projects for the introduction of high-level talents. Its form has changed from the a simple cooperative exchange to a cooperative research led by our country. At the same time, since our country's international status has been continuously improved and our exchanges and cooperation with countries in the world has become closer, the region of international exchange and cooperation has gradually shifted to some developing countries in Asia and Africa, therefore, the areas of the cooperation are getting broader. Judging from the actual situation of international exchange cooperation, the main region of the International Exchange and Cooperation in China's Colleges and Universities are Guangzhou, Shanghai, Beijing, Shenzhen and other developed regions, and the level of international exchanges in economically underdeveloped regions is relatively backward. It shows that there are still geographical characteristics of international exchanges and cooperation in colleges and universities. It is necessary for us to clarify the current situation and existing problems of international exchanges and cooperation in the process of China's international exchanges and cooperation. We should give full play to the important role of exchange and cooperation, and promote the sustained and stable improvement of the quality of running colleges and universities in China through various forms and ways of open communication activities. ${ }^{[3]}$

\subsection{Lacking of foundation for discipline construction}

Although China's economy has developed rapidly and the international status of our country has been effectively improved since the reform and opening up, compared with the developed countries, there is still a certain gap between China and the developed countries, and it is still in the stage of developing countries. The educational and scientific research equipment, subject team and scientific research funds in colleges and universities is insufficient due to a shortage of financial funds, and their resource allocation and infrastructure allocation still need to be improved. The allocation of resources in many disciplines is seriously insufficient, and there are some problems in the construction of basic disciplines, which affect the rational development of related scientific research projects, and it is difficult to attract first-class international talents and affect the quality of scientific research in our country. Secondly, the international teaching staff of our country is relatively weak, and the reserve of talents is also insufficient currently. Therefore, it is difficult for the colleges and universities of our country to exchange and cooperate with foreign colleges and universities on a full and equal basis, which affects the smooth development of exchanges and cooperation between colleges and universities in China. ${ }^{[4]}$

\section{A probe into the ways to deepen the International Exchange and Cooperation in Colleges and Universities}

\subsection{Strengthening the Internationalization of the Training of the Talents}

The purpose of international exchange cooperation in colleges and universities is to improve the teaching level of the higher education. Based on the main objectives and concrete forms of international exchange in colleges and universities, we can divide the connotation of international exchange activities into the following aspects, such as the cultivation of subject construction talents, the cultivation and optimization of campus culture teachers, the construction of campus culture, and so on. Campus culture construction, etc. First of all, we should pay attention to the internationalization of talent training, and directly express the internationalization degree of colleges and universities and the internationalization level of talent training through the level of talents in the process of 
internationalization of higher education. The university needs to strengthen the research on the teaching form and content of education in all countries of the world, and we should add the research content of the world's higher education into the work of colleges and universities. For colleges and universities with relatively abundant funds and large scale, we can carry out targeted educational reform research through the construction of special foreign higher education research institutions and research teams. We can also fully absorb and draw on the experience of the advanced state-of-the-art education and teaching, so as to promote the service reform of the university education in our country. ${ }^{[5]}$ Secondly, English, as an international language, plays an important role in academia and scientific research. Many world conferences and scientific research cooperation are carried out and communicated in English. Therefore, colleges and universities in China also need to strengthen the construction of international majors and courses taught in pure English. International major and curriculum teaching contents should be the international advanced level of original teaching materials. We should use English as the language of instruction, and train international talents in colleges and universities, increase the proportion of international major and curriculum settings in English teaching, so as to fully train high-level international comprehensive talents. We can effectively improve the English communication ability of our students, the application ability of English language and the level of Chinese academic and international integration, and improve the teaching environment of education through the construction of international professional and course. Meanwhile, the design of international majors and courses in colleges and universities of our country can also create a good educational and teaching environment for foreign students to study abroad and for us to recruit foreign students, solve the problem of language barrier, expand the scale of international students and increase the introduction of professionals. The design of international curriculum and professional good curriculum can also reflect the international characteristics of educational and teaching activities in our country, which is conducive to the smooth development and implementation of international cooperation projects, and promotes the exchange activities and cooperation projects between teachers and students between schools. In addition, the construction of international majors and courses can also speed up the reform of the training and education model in our country, introduce international advanced teaching methods, teaching contents, teaching ideas and teaching means, and improve the overall teaching quality and educational level. ${ }^{[6]}$ We can carry out the educational and teaching activities in the form of Chinese-foreign cooperation in running school, overseas schools and joint training of double campuses in the process of international exchanges and cooperation. The Chineseforeign cooperation in running school is an important form of the current international exchange and cooperation, and it is also an important form of the education input. The introduction of courses from foreign cooperative colleges and universities in domestic schools, as well as the entire academic education system, can enable the students to obtain double degrees from cooperative colleges and universities, as well as degrees from domestic colleges and universities, so that students can accept foreign high-quality education resources and reduce the investment of funds for studying abroad. Through the use of foreign advanced education and teaching methods, colleges and universities can also introduce substantive teaching resources and courses to promote the reform of education and teaching in their own schools, so as to make the reform more thorough and deepening.

The mode of double campus co-cultivation does not introduce the teaching resources and substantive courses, but emphasizes the mutual recognition and mutual connection of the teaching content. Alma mater recognizes the academic performance and learning content of foreign cooperative colleges and universities, and foreign cooperative colleges and universities become an important part of students to complete university learning activities. The core of double campus cocultivation is credit mutual recognition. The mode of double campus co-cultivation can be subdivided into the foreign actual mode, the basic plus professional mode and the double degree joint training mode and so on. Running a school abroad is to import the excellent domestic education and teaching resources and high-quality courses into foreign countries, to reflect the advantages of education and teaching in our country, and to promote the export of our culture. At present, Confucius College is the main form of Chinese promotion, and has been effectively recognized all over the world. In addition, the education of educational background export and the education of professional 
characteristics in our country have also been promoted rapidly. With the development of our country's economy and the increase of the international influence, the main form of international exchange cooperation in colleges and universities will be running schools abroad in the future, which may reflect the New growth Point of International Exchange and Cooperation. ${ }^{[7]}$

\subsection{Improving the talent cultivating mechanism}

The development and construction of high-level teacher staff is a prerequisite to ensure the smooth development of international exchange and cooperation. We should carry out the construction planning of the teaching staff in an international educational teaching concept, formulate the goal that matches the teacher's internationalization development, and construct the effective system. Firstly, we should also provide certain financial support for teachers to visit and study abroad, and send outstanding teachers to attend international academic conferences to carry out international academic discussions and exchanges. We must actively encourage students to participate in international scientific research cooperation projects and improve their international scientific research level. After teachers being trained abroad return home from abroad, they can integrate the international teaching concept and atmosphere into the actual teaching activities, and promote the long-term and effective development of educational and teaching activities in our country. Secondly, the domestic universities can invite foreign well-known scholars to carry out a series of lectures on science and technology and academic class, so they can bring high-quality education teaching resources and scientific research ideas to our students, thus further realizing the sharing of educational resources. Thirdly, Colleges and universities also need to establish a personnel system in line with China's national conditions and in line with international standards, encourage scientific research activities and international exchanges and cooperation, improve the international level of teacher staff, and give international talents a certain right of allocation of funds, autonomy of scientific research and personnel management as well. In the meantime, we should formulate a series of welfare system and incentive system related to the foreign cooperation and communication of university teachers, improve the enthusiasm and initiative of international exchange and cooperation of teachers, and realize the internationalization of teachers. In addition, we also need to innovate the form of co-operation and exchange, and to further promote the domestic and foreign educational research and exchange activities with Chinese-foreign cooperatively-run schools as the carrier. We can try to master and understand the latest subject trends and academic situation, improve the level of academic internationalization, and promote the further development of educational and teaching activities in our country through international teaching, teachers can innovate the original teaching ideas.

\subsection{Strengthen the connection between colleges and universities and the international community}

The influence of our country in the world is enhancing due to the development of Chinese social economy and the continuous improvement of its comprehensive strength. Under the background of economic globalization, the exchange between China and the international community has become a normal state, which provides a good opportunity for the international exchange activities of colleges and universities in our country, and also provides an important platform for the exchange and cooperation between colleges and universities at home and abroad. It can promote the exchange and cooperation of international colleges and universities and promote the sustainable and stable development of education in our country through the educational model of combining of international education and domestic education. Colleges and universities should promote international exchanges and cooperation, improve the level of scientific research and education in colleges and universities in China by making full use of the various carriers and platforms of international exchanges to promote international exchanges and cooperation.

\section{Conclusion:}

In conclusion, international exchange and cooperation in colleges and universities is the general trend of current educational and teaching activities. The scientific and systematic international cooperation 
exchange can promote the overall improvement of the teaching quality in our country, improve the scientific research level of our country, and can also create good conditions and provide continuous talent support for the sustainable and stable development of our economy. This paper mainly explores the importance of international exchange and cooperation in colleges and universities, points out the problems existing in the process of exchange and cooperation, and puts forward some concrete measures for solving them. The author hopes to further promote the international exchange and cooperation projects in colleges and universities, integrate the resources of the school and promote the sustainable development of education and teaching.

\section{Acknowledgment}

Research on the international cooperative training mechanism of innovative applied talents in northern university for nationalities under the strategy of "One Belt And One Road", a major research project on education and teaching reform of northern university for nationalities -- a case study of college of design and art (2019ZHJY01)

\section{References}

[1] Xiang Yin. Research on the Countermeasures of Foreign Affairs Informatization in Local Colleges and Universities in the New period. [J]. New Campus (lst Ten-days), 2017 (07): 33-34.

[2] Zhang Junhua. Preliminary study on how to stimulate students' interest in ideological and political Teaching in Colleges and Universities. [J]. Modern Vocational Education, 2017 (15): 61.

[3] Zuo Fang. The present situation and Countermeasures of the internationalization of higher Education in China. [J]. Good parents, 2015 (37): 256.

[4] Li Peng, Liu Chengjia. Understanding of International Exchange and Cooperation in Chinese Colleges and Universities. [J]. China Power Education,2012 (26):10-11.

[5] Gao Wei.Analysis on the problems and Countermeasures of International Exchange and Cooperation Development in Local Colleges and Universities. [J]. Modernization of Education, 2016, 3 (27): 238-240.

[6] Ma Deyi.Networking: a New trend in the Development of International Cooperation in Colleges and Universities. [J]. Educational Research, Tsinghua University, 2004 (8) P91-96.

[7] Zhou Lintu.On the horizontal combination of higher Education under the background of internationalization of Education. [J]. Journal of Changchun University of Technology, 2003, (6), P14-16. 